\title{
Human Security as Political Resource: A Response to David Chandler's "Human Security: The Dog that didn't Bark" \\ David Ambrosetti
}

French National Centre for Scientific Research (CNRS) / University Paris X, Nanterre, France

From an academic standpoint, I see two ways to deal with the current, influent discourse of 'human security'. The first one consists in assessing the internal logic of the arguments supporting (or contesting) the new doctrine, and in foreseeing their expected political and ethical consequences with the use of logical reasoning. Although valuable, such exercises present a risk: as Pierre Bourdieu (1990: 48-51) has put it (following Marx), it is a frequent mistake from 'professional exponents of logos and logic' to 'take the things of logic for the logic of things'. In reaction, the second, more sociological way favours long-term empirical analyses focused on the transforming and unchanged practices surrounding the new doctrine and their consequences for the concerned actors, in terms of resources, social/political positions and hierarchies, 'rules of the game', stability and change, etc.

The major interest of David Chandler's (2008) review is to call for critical distance and empirical research as regards human security, in order to understand the growing appropriation of this discourse by state officers and bureaucratic decision-makers. This is the core of his quite severe criticism on Shahrbanou Tadjbakhsh and Anuradha M. Chenoy's (2007) Human Security: Concepts and Implications. These authors do not propose in-depth empirical analyses on that matter, although they do admit the possibility of such politically-oriented appropriation when they discuss the relation between human security and the 'responsibility to protect', as well as the interventionist and discretionary content of this doctrine.

The second book discussed by Chandler, A Decade of Human Security: Global Governance and New Multilateralisms, edited by Sandra MacLean, David Black and Tim Shaw (2006), meets his expectations more accurately. The authors are more sceptical of the new 'paradigm'. And their approach is more empirical. They give more importance to the relations between discourse and actual practice, and between both discourse and practice and the existing political hierarchies. These authors show interestingly the clear absence of any systematic codification regarding collectively expected practices in response to well defined 'threats'. This enables the discretionary and interventionist use of the human security discourse by powerful governments or by increasingly powerful bureaucratic actors, with the tacit support of its many advocates or at least without any open opposition from them. This is the main challenge for the doctrine in terms of institutionalisation and global credibility.

In this regard, the three reasons proposed by Chandler (2008) in his conclusion as a means to explain the rapid integration of human security approaches into mainstream security agendas (they have exaggerated new post-Cold War security threats, have located these threats in the developing world, and have facilitated short-term policymaking in the absence of clear strategic foreign policy visions) deserve to be taken very seriously in further empirical research, as they seem the most credible ones. Chandler opportunely refers to the tendency to replace political stakes between opposing groups with non-political, 'technical' considerations about the existing threats and their 
interconnections. This is one of the vulnerabilities of this discourse, allowing it to be shaped 'conservatively' by powerful actors in an interest-based (but not necessarily state-based) perspective.

Nevertheless, a purely 'empiricist' approach would not valid too hastily such a 'the more things change, the more they stay the same' view without further investigation either. To assay the 'reality' of the observed changes is a difficult task, a difficulty depending on the period and the scope of the observation. Although I sympathize with David Chandler's aim of restoring politics and competition for power to the heart of the analysis - an aim that stands opposed to 'wishful thinking' assertions on the revolutionary nature of human security approaches - there is a risk that theoretical possibilities may be dismissed or deprecated too quickly simply on the grounds that human security approaches have not yet brought them about.

More particularly, as an important warning for the analysts, the author is keen to point out the potential use of this new rhetoric for both reproducing existing decisional positions and diluting political responsibilities among diverse national and international bureaucratic officers and experts acting on an ad hoc basis (Chandler, 2007). Such warning deserves to be largely echoed. But new doctrines may induce changes that do not affect, or do not initially affect, the hierarchy of power between existing actors. These potential changes may firstly concern the content of the power relationships, the type of rule, that is, the rules shared by unchanged dominated and dominating actors (Onuf, 1989). Of course this would be a disappointing 'revolution', a modest change, but this hypothesis deserves in my view to be theoretically envisaged and empirically tested as well. Moreover, this would-be change of the 'rules of the game' may trigger efforts at adjustments that might leave room either for the conquest of influence and power by previously dominated actors, or for the reinforcement of already dominant actors. Whether this turned out to be the case would require empirical demonstration in the long run.

In that regard, I am not completely convinced that Tadjbakhsh and Chenoy make logically 'collapse' their claim when they assert that 'human security transforms, rather than replaces the national security discourse and is not an alternative to state security'. The permanence of the competition for power between organized individuals (within states for instance) seems theoretically compatible with a normative shift institutionalising individual freedom from physical threats. It seems undeniable that security concerns involve "political processes of collective decision-making, choices and policy trade-offs'. But to assert that 'the individual qua person becomes the ultimate actor taken into account', 'the ultimate goal', does not exactly mean that every single individual qua person is able to assure his or her freedom from physical threats by himor herself. What is at stakes underneath is the possible recognition of a new principle serving as a new normative boundary in political competitions and processes. Although political associations and collective processes around competitive stakes and conflicting security concerns seem unavoidable, they might operate through changing 'rules of the games' where threats on individual physical integrity can be severely and collectively regulated or even banned. From a practical point of view, such an outcome seems improbable. But from a theoretical point of view, one can admit it may happen, at least in a limited social space and during a limited length of time. 
What are the factors that deserve to be considered in order to assess empirically the outcomes of a discourse like human security? A recent trend in IR literature (among liberal constructivists essentially) is to focus on explicit arguments and evoked principles and norms. Ronald R. Krebs and Patrick T. Jackson, however, convincingly stressed the methodological risks in these attempts to demonstrate persuasion in political trade-offs and negotiations (Krebs and Jackson, 2007). I drew the same conclusion and insisted on the entrenchment of arguments and other political resources after assisting and analyzing a specific negotiation within the UNSC (Ambrosetti, 2004). Let me, then, expose a methodological frame inspired by my own research on the humanitarian discourse and the interventionist practices of diplomatic decision-makers at the UN Security Council, in a sociological perspective (Ambrosetti 2005a, 2005b, 2006). It may offer a way to deal with human security discourse as a political resource and to assess its possible outcomes empirically.

The individual who hold such a decision-making position needs meet different collective expectations from different audiences in order to preserve his/her position. These expectations are attached to various other specific positions held in these different audiences and groups. Some of these positions are strongly formalised, whereas others are more pervasively acknowledged - and more exposed to changes, to risks of deprivation. These various specific social positions constitute altogether the political resources that enable him/her to hold the studied decision-making position.

The grasp of a new discourse - as human security - by diplomatic decision-makers needs be understood in regard to this social environment where expectations and resources intermingle. Resources only exist in relation to the particular groups that behave as to make these resources exist. And they only exit in relation to the particular groups that recognize them as resources. Thus, for an 'appropriate' use of their resources, decision-makers must abide by the rules whereby these groups keep behaving the way they do. And these rules are constructed in the different audiences composing the decision-makers' social environment (Onuf, 1989: 64; March \& Olsen, 1998). In this environment can be identified regularities and learning processes concerning the opportunities and risks attached to these resources.

The human security discourse would not have been accepted and seized by state officers if it immediately appeared as an insuperable obstacle that threatened the relative positions of these actors in the competitive games between different diplomacies and within their own bureaucracies. This means that the human security discourse did not seem to represent an unacceptable direction to those who provide state officers with the resources that enable the latter to maintain their elevated political positions.

This absence of perceived threats and hostile expectations must be established empirically. For instance, the social 'work' whereby would-be previously perceived threats have been overcome in specific cases must be understood. But the rationale of the success of the human security notion may lie in the newness of the term and its lack of precision, that is, in the plasticity of the content it would be given. As with every new principle, the human security principle authorises different interpretations, urgencies and translations in political agendas; it allows progressive moulding in one direction or the other, according to processes of public argumentation and private bargaining. In this sense, Chandler is right to highlight the possibilities of cooptation inherent in the manipulation of this human security principle, as a major reason of its 'mainstreaming'. 
However, any political investment in such a new "label" would have been useless, had this label not proved its ability to trigger more or less tacit forms of acquiescence in diverse large audiences outside the international diplomatic scene, according to the legitimacy these audiences accord to it. A genealogy of the term would certainly show how it serves to "invite" new audience with individualistic/universalistic preferences to enter the field of security debates and to "naturally" support different forms of interventionist and intrusive practices against "old-fashioned" state-centred scholars. What I intended to prove concerning the humanitarian discourse might well be applied to the new rhetoric of human security.

By no means do I state that anything can be done with the human security rhetoric. The outcome of this rhetoric depends on the actors (with their unequal resources) and audiences who are involved, who feel concerned by this notion and engaged by what is done in its name. Will this or that interpretation be considered to be completely normal or at least acceptable by a large number of these actors and audiences? If not, the one who states such interpretations may expect reactions from others who will not recognise the human security agenda and will then empty it of its symbolic and institutional value.

The question is therefore: what remains possible and impossible to do, or collectively acceptable and unacceptable, or probable and improbable, within specific audiences once this principle is invoked and repeated? What are the precise normative changes induced by the repeated use of this principle, even with pure rhetorical intentions? Concerning Chandler's discussion, my argument calls for empirically assessing the opportunities but also the risks state decision-makers and international officers are exposed to, regarding the different audiences which provide them with their main political resources, when they evoke the notion of human security.

A new principle with a largely-acknowledged legitimacy must thus be analysed as a new resource for political mobilisation available for the traditional actors, or for newlyconstituted ones. It will merge with other forms of political resources, according to the 'rules of use' of these existing resources and the capacity of innovation of the actors. Nothing allows defining in advance the outcome of the new competition that will rise around this new principle understood as a new resource, nor the new rules and norms that will appear (or not) in the use of this resource and their political consequences. The invocation of human security can foster emancipation for some and at the same time new submission for others. The outcome of this invocation depends on successful linkages between the practices enacted in the name of human security and this very principle, that is, on the acceptability of the former in regard of the latter. And this outcome must be assessed in accordance with the symbolic and material resources mobilised in order to support and secure these linkages.

In this analytical framework, it is useless to oppose power-maximizing practices and ethical, valued-centred 'motivations', as is often done in both books discussed by David Chandler. Against this quite infertile dichotomy, social scientists can only observe transforming or unchanging practices surrounding new invoked doctrines such as human security, and their political consequences. But they may also understand more deeply how actual dominant norms and practices from state officers and decisionmakers can (or cannot) practically integrate concerns stressed by human security approaches, and with which potential political consequences. What remains important 
here is to avoid hasty overall judgments on the human security principle on a binary (emancipatory or conservative) basis, and to call again for deep empirical research on the practical uses of the human security rhetoric and the shifts they may provoke over time in the balance of power and the rules of the political competitions between the different actors.

References

Ambrosetti, David, 2004. 'Opposing United States in the UN Security Council: Arguing vs. Power in Multilateral Negotiations', Études internationales 35 (3): 469-494 (in French).

Ambrosetti, David, 2005a. 'Humanitarian as a Discursive Norm within the UN Security Council: a socially sanctioned Legitimating Practice', Cultures \& Conflits 60: 39-62 (in French).

Ambrosetti, David, 2005b. International Politics as a Sphere of Social Judgment: French Diplomacy Legitimating Practices in UN Conflict Management. PhD Dissertation, Bordeaux: University Montesquieu-Bordeaux IV (in French).

Ambrosetti, David, 2006. 'UN Peace Operations and the Risk of an Irremediable Discredit: Between Weakness and Selectivity', Studia Diplomatica 59 (2): 123-139 (in French).

Bourdieu, Pierre, 1990. The logic of Practice. Stanford: Stanford University Press.

Chandler, David, 2007. 'The security-development nexus and the rise of "anti-foreign policy", Journal of International Relations and Development 10 (4): 362-386.

Krebs, Ronald R. \& Patrick Thaddeus Jackson, 2007. 'Twisting Tongues and Twisting Arms: The Power of Political Rhetoric', European Journal of International Relations 13 (1): 35-66.

Maclean, Sandra J., David R. Black and Timothy M. Shaw (eds), 2006. A Decade of Human Security: Global Governance and New Multilateralisms. Aldershot \& Burlington, VT: Ashgate.

Onuf, Nicholas G., 1989. World of Our Making. Rules and Rule in Social Theory and International Relations. Columbia: University of South Carolina Press.

Tadjbakhsh, Shahrbanou \& Anuradha M. Chenoy, 2007. Human Security: Concepts and Implications. London \& New York: Routledge.

March, James and Johan Olsen, 1998 'The Institutional Dynamics of International Political Orders', International Organization 52 (4): 943-69. 